Article

PAZUCH, D. ${ }^{1}$

TREZZI, M.M. ${ }^{1 *}$

GUIMARÃES, A.C.D. ${ }^{2}$

BARANCELLI, M.V.J. ${ }^{1}$

PASINI, R. ${ }^{1}$

VIDAL, R.A. ${ }^{3}$

\section{Evolution of Natural Resistance to Glyphosate in MORNing GLORY POPUlations}

\author{
Evolução da Tolerância ao Glyphosate em Populações de Corda-de-Viola
}

* Corresponding autor:

<trezzi@utfpr.edu.br>

Received: March 19, 2016

Approved: April 20, 2016

Planta Daninha 2017; v35:e017159430
ABSTRACT - Tolerance, also referred to as natural resistance, is a feature that exists in the plant even before herbicide application in an area. I. grandifolia, I. indivisa and I. purpurea are among the tolerant species most commonly found over fields in southern Brazil. We hypothesized that the intensive use of glyphosate results in increasing levels of tolerance to glyphosate, and in pronounced response variability in populations of the same Ipomoea species. This study aimed at identifying tolerance variations to glyphosate among I. grandifolia, I. indivisa and I. purpurea morning glory species and among populations of these species. In crops over Paraná and Santa Catarina states (Brazil) 31 biotypes were collected (20 I. grandifolia, 7 I. indivisa and $4 I$. purpurea), on which were applied 0, 216, 432, 864, 1,296, 1,728 and $2,160 \mathrm{~g}$ a.e. ha ${ }^{-1}$ of glyphosate and the dose required to reduce $50 \%$ of dry matter $\left(\mathrm{GR}_{50}\right)$ was determined. Biotypes of all tested Ipomoea species showed variability of glyphosate tolerance. Tolerance factors had greater amplitude among biotypes of I. gradifolia and I. indivisa species (between 1.7 and 33.6 and between 3.3 and 34.2, respectively) than in I. purpurea (between 3.7 and 4.9). Especially within I. gradifolia e I. indivisa species, some biotypes required a much higher dose than the recommended one to control the wild biotype, indicating progress in the level of glyphosate tolerance; this proves the initial hypothesis of this work.

Keywords: tolerance, Ipomoea grandifolia, Ipomoea indivisa, Ipomoea purpurea, control, dose-response.

RESUMO - A tolerância, também referida como resistência natural, é uma característica existente na planta mesmo antes da aplicação do herbicida em uma área. As espécies de corda-de-viola I. grandifolia, I. indivisa e I. purpurea estão entre as espécies tolerantes ao glyphosate mais comumente encontradas em lavouras do Sul do Brasil. Hipotetiza-se que o uso intensivo de glyphosate incrementa os níveis de tolerância e, consequentemente, acentua a variabilidade de resposta ao herbicida em populações da mesma espécie de Ipomoea. Os objetivos deste trabalho foram identificar variações de tolerância ao glyphosate entre as espécies de cordade-viola I. grandifolia, I. indivisa e I. purpurea e entre populações dentro de cada uma dessas espécies. Em lavouras das regiões Sudoeste do Paraná e Oeste de Santa Catarina foram coletados 31 biótipos (20 de I. grandifolia, 7 de I. indivisa e 4 de I. purpurea), nas quais foram aplicados 0, 216, 432, 864, 1.296, 1.728 e $2.160 \mathrm{~g}$ e.a. ha $\mathrm{h}^{-1}$ de glyphosate e foi determinada a dose necessária para redução de $50 \%$ da matéria seca da parte aérea $\left(G R_{50}\right)$. Plantas dos biótipos das três espécies de Ipomoea apresentaram variabilidade na tolerância ao glyphosate. Os fatores de tolerância apresentaram maior amplitude entre biótipos nas espécies I. grandifolia e I. indivisa (entre 1,7 e 33, 6 e entre 3,3 e 34,2, respectivamente) do que em I. purpurea (entre 3,7 e 4,9). Especialmente nas espécies I. grandifolia e

1 Universidade Tecnológica Federal do Paraná (UTFPR), Pato Branco-PR, Brasil; ${ }^{2}$ Universidade do Estado de Mato Grosso, Alta Floresta-MT, Brasil; ${ }^{3}$ Universidade Federal do Rio Grande do Sul, Porto Alegre-RS, Brasil. 
I. indivisa, alguns biótipos necessitaram de dose muito superior à recomendada para o controle do biótipo selvagem, indicando evolução no nível de resistência natural ao herbicida glyphosate, o que comprova a hipótese deste trabalho.

Palavras-chave: resistência natural, Ipomoea grandifolia, Ipomoea indivisa, Ipomoea purpurea, controle, dose-resposta.

\section{INTRODUCTION}

Ipomoea has 600 to 700 species, constituting the biggest number of species from the Convolvulaceae family (Lorenzi and Souza, 2001); many of them are considered weeds. They are widely distributed in tropical and subtropical regions, with lower occurrence in temperate climates (Cao et al., 2005). These plants present different germination flows during spring and summer, due to seed dormancy (Ogunwenmo and Ugborogho, 1999; Azania et al., 2009).

Ipomoea plants cause yields losses and big problems to harvests and grain quality in important cultivated species. The impact of Ipomoea spp. plants on soybean yields can reach $80 \%$ (Norsworthy and Oliver, 2002). Growth habit allows them to climb up cultivated plants and cause losses in the effectiveness of the mechanized harvest (Kissmann and Groth, 1999). Moreover, the plants damage grain quality, due to the increase in humidity and impurity in the harvested product (Kissmann and Groth, 1999).

Over the last years, modifications in the composition of emerged weed species and in the seed bank, due to intense glyphosate use, have been documented in various countries. Interspecies selection results in flora changes for the most tolerant species. Natural resistance is an existing characteristic in the plant, even before herbicide application in an area (Duke, 2011). After continuous applications of an herbicide with a single action mechanism, there is a natural selection of plants that are poorly affected by its use (Christoffoleti, 2008). Worldwide, many weed species have been described as glyphosate-tolerant, such as Ambrosia artemisiifolia (Kapusta et al., 1994), Sesbania exaltatta (Jordan et al., 1997), Commelina benghalensis (Monquero et al., 2004), Richardia brasiliensis, Borreria latifolia and Tridax procumbens (Galon et al., 2009).

Ipomoea species are among the most glyphosate-tolerant ones (Monquero et al., 2004). Intraspecies differences in glyphosate tolerance may also occur in some species, such as Convolvulus arvensis (Degennaro and Weller, 1984).

Over the last years, an increased level of difficulty in controlling Ipomoea populations has been observed in the Southern states of Brazil. It is thought that an intensive glyphosate use results in increased levels of natural resistance to the herbicide and, consequently, in an accentuated response variability to the herbicide in populations from the same Ipomoea species. The goals of this work were to identify glyphosate tolerance variations among I. grandifolia, I. indivisa and I. purpurea morning glory species and among populations within each one of them.

\section{MATERIAL AND METHODS}

Seeds from Ipomoea spp. plants were collected in glyphosate-resistant genetically modified soybean cultivations from producers in the regions of Southwestern Paraná state and Western Santa Catarina state. Inflorescences were air-dried for 72 hours, and seeds were manually extracted and separated with sieves. Thirty-one populations were collected: three in Santa Catarina state and 28 in Paraná state (Table 1). Taxonomic identification at species level was performed by a specialist, based on inflorescence and seed characteristics of plants from the collected populations.

Three experiments, one for Ipomoea grandifolia, one for I. indivisa and one for I. purpurea, were simultaneously conducted in a greenhouse/fenced field area; the climate was classified as humid subtropical (Cfa), with $766 \mathrm{~m}$ average height.

The design used in each experiment was the completely randomized one, with four replications. In each experiment, treatments were set in bifactors: the first factor was constituted 
Table 1 - Biotype, species and place of origin of each studied biotype

\begin{tabular}{|c|c|c|}
\hline Biotype & Ipomoea Species & City - State \\
\hline 1 & I. indivisa & São Domingos - Santa Catarina state \\
\hline 2 & I. grandifolia & Renascença - Paraná state \\
\hline 3 & I. grandifolia & Renascença-Paraná state \\
\hline 4 & I. grandifolia & São Domingos - Santa Catarina state \\
\hline 5 & I. grandifolia & Santo Antônio do Sudoeste - Paraná state \\
\hline 6 & I. grandifolia & Santo Antônio do Sudoeste - Paraná state \\
\hline 7 & I. indivisa & Renascença-Paraná state \\
\hline 8 & I. grandifolia & Renascença-Paraná state \\
\hline 9 & I. purpurea & Renascença-Paraná state \\
\hline 10 & I. indivisa & Renascença-Paraná state \\
\hline 11 & I. grandifolia & Renascença-Paraná state \\
\hline 12 & I. grandifolia & Mariópolis - Paraná state \\
\hline 13 & I. grandifolia & Renascença - Paraná state \\
\hline 14 & I. grandifolia & Santo Antônio do Sudoeste - Paraná state \\
\hline 15 & I. grandifolia & Renascença - Paraná state \\
\hline $16^{*}$ & I. grandifolia & Mariópolis - Paraná state \\
\hline 17 & I. purpurea & Renascença - Paraná state \\
\hline 18 & I. grandifolia & Pato Branco - Paraná state \\
\hline 19 & I. grandifolia & Pato Branco - Paraná state \\
\hline 20 & I. indivisa & São Domingos - Santa Catarina state \\
\hline 21 & I. grandifolia & Pato Branco - Paraná state \\
\hline 22 & I. grandifolia & Pato Branco - Paraná state \\
\hline 23 & I. indivisa & Pato Branco - Paraná state \\
\hline 24 & I. grandifolia & Pato Branco - Paraná state \\
\hline $25^{*}$ & I. purpurea & Pato Branco - Paraná state \\
\hline 26 & I. grandifolia & Pranchita - Paraná state \\
\hline 27 & I. indivisa & Pato Branco - Paraná state \\
\hline 28 & I. grandifolia & Pato Branco - Paraná state \\
\hline 29 & I. purpurea & Nova Esperança do Sudoeste - Paraná state \\
\hline $30 *$ & I. indivisa & Pato Branco - Paraná state \\
\hline 31 & I. grandifolia & Santo Antônio do Sudoeste - Paraná state \\
\hline
\end{tabular}

* Biotypes collected in an area without selection pressure by glyphosate.

by Ipomoea biotypes (20 biotypes in the experiment with I. grandifolia, 7 in the one with I. indivisa and 4 in the one with I. purpurea) (Table 1) and the second factor was constituted by glyphosate concentrations $\left(0,216,432,864,1,296,1,728\right.$ and $2,160 \mathrm{~g} \mathrm{ha}^{-1}$ of acid equivalent).

Pots were filled with $4,400 \mathrm{~cm}^{3}$ of Distroferric Red Latosol, which were sieved and fertilized with $70 \mathrm{~kg} \mathrm{ha}^{-1}$ fertilizer containing $\mathrm{N}-\mathrm{P}_{2} \mathrm{O}_{5}-\mathrm{K}_{2} \mathrm{O}$, according to the indication of soil analysis. Texture analysis indicated $55.7 \%$ clay, $41.3 \%$ silt and $3 \%$ sand.

Seeds underwent treatments to overcome dormancy, with hot water at $98{ }^{\circ} \mathrm{C}$ for I. grandifolia biotypes and with concentrated sulphuric acid (98\%) for I. purpurea and I. indivisa ones (Pazuch et al., 2015); after that, five seeds were planted per each biotype, leaving three plants per pot after thinning. The plants remained in a greenhouse with temperature control system $\left(10{ }^{\circ} \mathrm{C}\right.$ minimum and $31^{\circ} \mathrm{C}$ maximum), cooling and automatic irrigation, with approximately $3 \mathrm{~mm}^{\circ}$ day $^{-}$ ${ }^{1}$ drip irrigation, until they presented two pairs of real leaves; subsequently, the pots were transferred to the fenced field area, containing a sprinkle irrigation system. In both irrigation systems, irrigation frequency and soil humidity control were performed through visual evaluation of soil and plant water conditions. Temperature and air relative humidity conditions of the period in the fenced field area environment are presented in Figure 1. 
In order to apply glyphosate, a manual backpack sprayer pressurized with $\mathrm{CO}_{2}$ was used, working under constant pressure, equipped with a three XR 110.02 fan type nozzle bar, spaced $0.5 \mathrm{~m}$ apart, positioned at $0.5 \mathrm{~m}$ above the target, applying $200 \mathrm{~L} \mathrm{ha}^{-1}$ spray volume. Application occurred during postemergence, when plants were in the stage with six to eight leaves. The used doses were defined after performing preliminary experiments for each one of the species. Environmental conditions at the beginning and at the end of applications were: wind speed $(\mathrm{m} / \mathrm{s})=0.75$ and 1.4 ; air relative humidity $(\%)=60$ and 65 ; and air temperature $\left({ }^{\circ} \mathrm{C}\right)=20.3$ and 19.7 , respectively.

On day 28 after treatment application

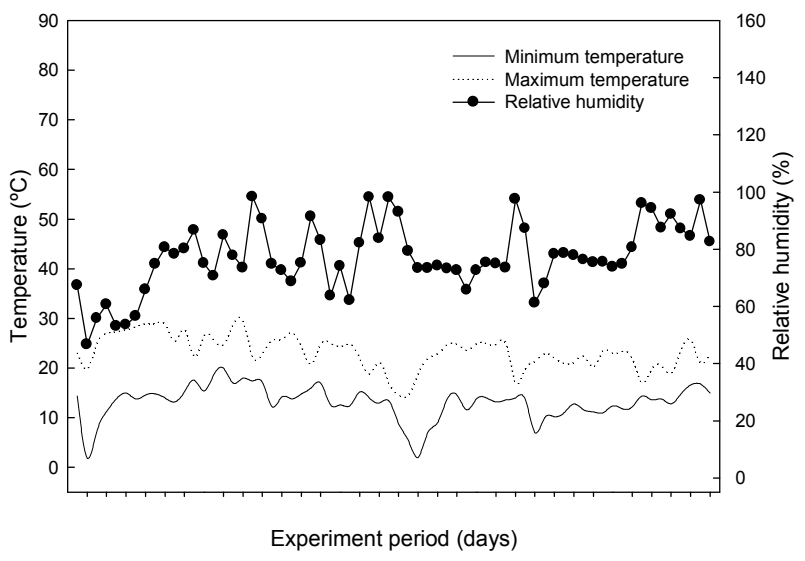

Figure 1 - Air relative humidity and minimum and maximum daily temperatures observed during the experiment in fenced field area environment. (DAA), the aerial parts of plants were collected near the soil, determining green aerial part mass (MPAV), and subsequently placed in a incubator at $60{ }^{\circ} \mathrm{C}$ until constant mass (for 72 hours approximately), to evaluate shoot dry mass (SDM). Tolerance factors (FTs) were calculated through the quotient of the herbicide dose necessary to reduce $50 \%$ of dry aerial part mass $\left(\mathrm{GR}_{50}\right)$ of each biotype by $\mathrm{GR}_{50}$ of the most sensitive biotype. The necessary herbicide dose to reduce $80 \%$ of the dry aerial part mass was also estimated, through an electronic spreadsheet (Microsoft Office Excel 2007).

Data were submitted to analysis of variance by $\mathrm{F}$ test and, in case of significance, the averages of the qualitative factor were compared through LSD test $(p=0.05)$. Averages of the $B$ factor were adjusted to nonlinear regression models, by three parameter sigmoid equation (Equation 1) and three parameter logistic equation (Equation 2), with the help of SigmaPlot 10.0 computer program (Sigmaplot, 2006). The three parameter sigmoid equation was used mainly because it properly adjusted the majority of response-dose curves. In case of adjustment absence, as a second option, it was decided to use the three parameter logistic equation

$$
\begin{aligned}
& y=\frac{a}{1+\exp \left[-\frac{x-x_{0}}{b}\right]} \\
& y=\frac{a}{1+a b s\left[-\frac{x}{x_{0}}\right]^{b}}
\end{aligned}
$$

in which: $y$ represents the response of the dependent variable, $x$ is the herbicide dose, $a$ is the curve maximum asymptote, $b$ is the curve gradient and $x_{0}$ represents the necessary dose to reduce by $50 \%$ the dependent variable.

\section{RESULTS AND DISCUSSION}

There was great glyphosate response variability among biotypes from the three Ipomoea species (Figures 2, 3 and 4 and Tables 2, 3 and 4).

For the I. grandifolia species, shoot dry mass (SDM) results indicated biotypes 28, 8, 5, 14,15 and 16 among the most sensitive ones, presenting SDM reduction above 80\% (Figure 2). Among the most tolerant ones, which presented the lowest SDM reduction, there are biotypes 19, 22, 18,24 and 12, with average reduction of $73 \%$ in relation to the control sample with no herbicide application. These results are confirmed by $\mathrm{GR}_{50}$ and $\mathrm{GR}_{80}$ and FT values (Table 3). Tolerance factors (FT) varied between 1.7 (biotypes 5 and 8) and 33.6 (biotype 19), which means that biotype 
19 needs a glyphosate dose 33 times bigger than the one necessary to reduce $50 \%$ of SDM than biotype 28, the most sensitive one. Biotype 16 was collected in an area with no glyphosate use history and, in spite of not being the most glyphosate-sensitive one, it was placed in the group of most sensitive biotypes, with 2.44 FT (Table 2).

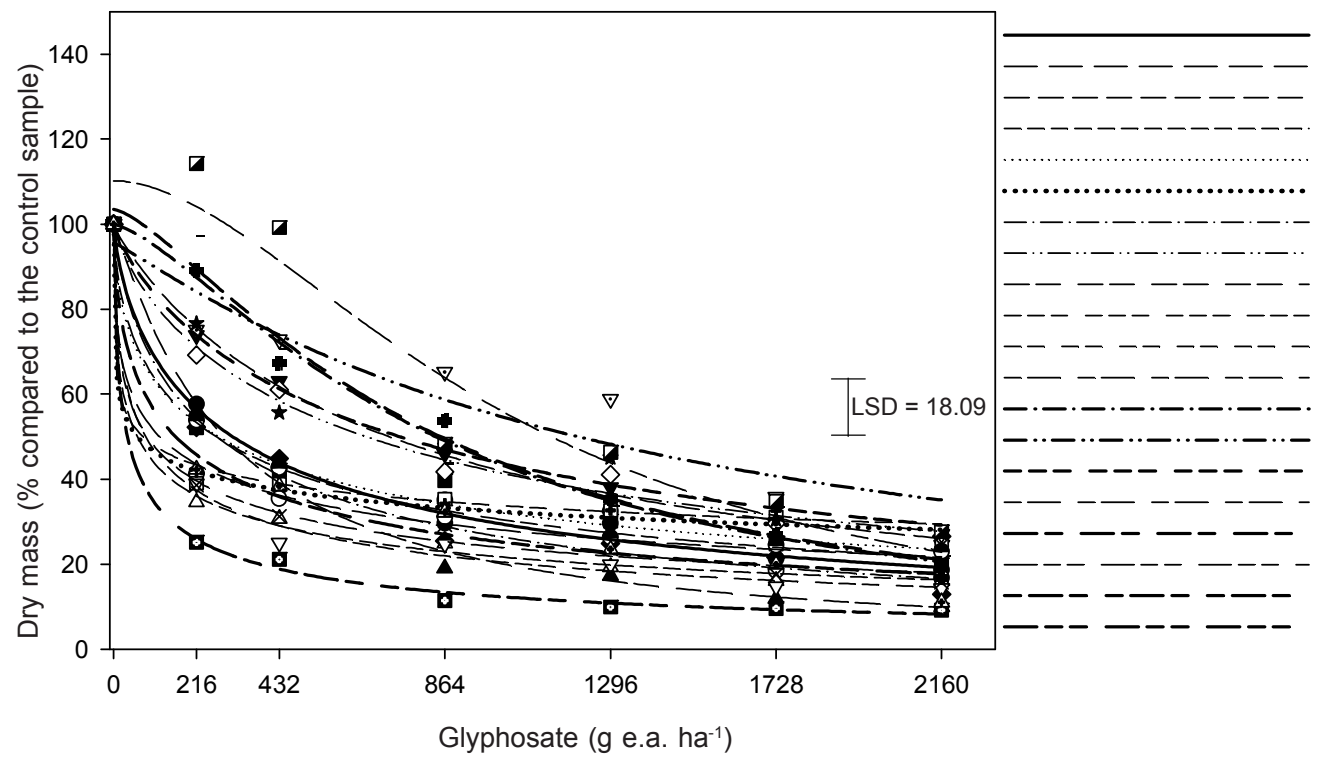

Biotype 2

Biotype 3

Biotype 4

Biotype 5

Biotype 6

Biotype 8

Biotype 11

Biotype 12

Biotype13

Biotype 14

Biotype15

Biotype 16

Biotype 18

Biotype 19

Biotype 21

Biotype 22

Biotype 24

Biotype 26

Biotype 28

Biotype 31

Averages compared by LSD test at $5 \%$ significance.

Figure 2 - Shoot dry mass in I. grandifolia biotypes on day 28 after the application of glyphosate treatments.

Table 2 - Parameters of the equations that were adjusted to shoot dry mass variable of $I$. grandifolia biotypes after glyphosate application

\begin{tabular}{|c|c|c|c|c|c|c|}
\hline \multirow{2}{*}{ Biotype } & \multicolumn{4}{|c|}{ Parameter $^{(1)}$} & \multirow{2}{*}{$\mathrm{GR}_{80} * *$} & \multirow{2}{*}{ Tolerance factor } \\
\hline & A & B & $\mathrm{GR}_{50} *$ & $\mathrm{R}^{2}$ & & \\
\hline 2 & 100.06 & 0.73 & 310.13 & 0.99 & 2.023 & 8.61 \\
\hline 3 & 99.90 & 0.44 & 120.88 & 0.96 & 2.732 & 3.33 \\
\hline 4 & 99.60 & 0.94 & 723.05 & 0.99 & 3.096 & 19.89 \\
\hline 5 & 99.97 & 0.46 & 62.15 & 0.99 & 1,258 & 1.72 \\
\hline 6 & 99.87 & 0.57 & 273.59 & 0.98 & 3,087 & 7.56 \\
\hline 8 & 99.97 & 0.26 & 61.78 & 0.99 & $>2,160$ & 1.72 \\
\hline 11 & 99.87 & 0.77 & 270.22 & 0.98 & 1,608 & 7.47 \\
\hline 12 & 99.77 & 0.8 & 661.07 & 0.98 & $>2,160$ & 18.22 \\
\hline 13 & 99.82 & 1.1 & 289.26 & 0.99 & 1,016 & 8.00 \\
\hline 14 & 100.01 & 0.54 & 83.47 & 0.99 & 1,067 & 2.33 \\
\hline 15 & 99.98 & 0.26 & 76.98 & 0.99 & $>2,160$ & 2.12 \\
\hline $16^{(2)}$ & 99.96 & 0.47 & 88.45 & 0.99 & 1,639 & 2.44 \\
\hline 18 & 99.81 & 1.43 & 842.14 & 0.98 & 2,208 & 23.31 \\
\hline 19 & 95.54 & 1.1 & 1316.62 & 0.85 & $>2,160$ & 33.56 \\
\hline 21 & 100.17 & 0.83 & 741.93 & 0.96 & $>2,160$ & 20.67 \\
\hline 22 & 110.16 & 1.81 & 1030.09 & 0.89 & 2,362 & 31.69 \\
\hline 24 & 103.45 & 1.4 & 812.96 & 0.96 & 2,254 & 23.67 \\
\hline 26 & 100.05 & 0.61 & 266.13 & 0.99 & 2,504 & 7.389 \\
\hline 28 & 99.99 & 0.58 & 36.05 & 0.99 & 380 & 1.00 \\
\hline 31 & 99.83 & 0.59 & 162.93 & 0.97 & 1,669 & 4.50 \\
\hline
\end{tabular}

(1) Three parameter logistic equation. $\mathrm{A}=$ maximum asymptote, $\mathrm{B}=$ curve gradient, $\mathrm{GR}_{50}=$ dose that provides a $50 \% \mathrm{SDM}$ reduction. $\mathrm{GR}_{80}=$ dose that provides a $80 \%$ SDM reduction. ${ }^{(2)}$ Biotype collected in area with no glyphosate application. * Estimated through SigmaPlot program. ** Estimated through Microsoft Excel program. 
As for the I. indivisa species, there was an SDM increase in biotype 20, with lower glyphosate doses - a physiologic phenomenon named "hormesis" (Duke et al., 2006). Biotypes 7 and 20 were the ones presenting lower SDM reductions and the highest $\mathrm{GR}_{50}$ values, as well as $\mathrm{GR}_{80}$ values that were higher than the maximum 2,160 $\mathrm{g} \mathrm{ha}^{-1}$ dose, whereas biotypes 30 and 27 were the most glyphosate-sensitive ones, demonstrating higher SDM reductions (Figure 3) and the lowest $\mathrm{GR}_{50}$ values (Table 3). $\mathrm{GR}_{80}$ values support the higher sensitivity of these biotypes to glyphosate (Table 3). For I. indivisa, FTs varied between 3.3 (biotype 27) and 34.2 (biotype 20). Biotype 30, the most glyphosate-sensitive one, was collected in an area without selection pressure by herbicide.

I. purpurea biotypes 9, 17 and 25 had their growth stimulated in two lower doses, indicating "hormesis". Biotypes presenting lower SDM reduction compared to the herbicide-free control sample were number 9 and 17 (Figure 4). Biotypes 17 and 9 presented the highest $\mathrm{GR}_{50}$ and $\mathrm{GR}_{80}$ values (Table 4), that is, they showed higher tolerance rates to glyphosate.

As for I. purpurea species, biotype 29, collected in an area with no glyphosate use history, was the most glyphosate-sensitive one, presenting lower $\mathrm{GR}_{50}$ than the others (Table 4). FT variability in $I$. purpurea was lower compared to the other studied species, presenting values between 3.7 (biotype 25, coming from an area without selection pressure by glyphosate) and 4.9 (biotype 17) (Table 4). This occurred because the $\mathrm{GR}_{50}$ value (SDM) of the most sensitive I. purpurea biotype was higher than the one of I. grandifolia and I. indivisa.

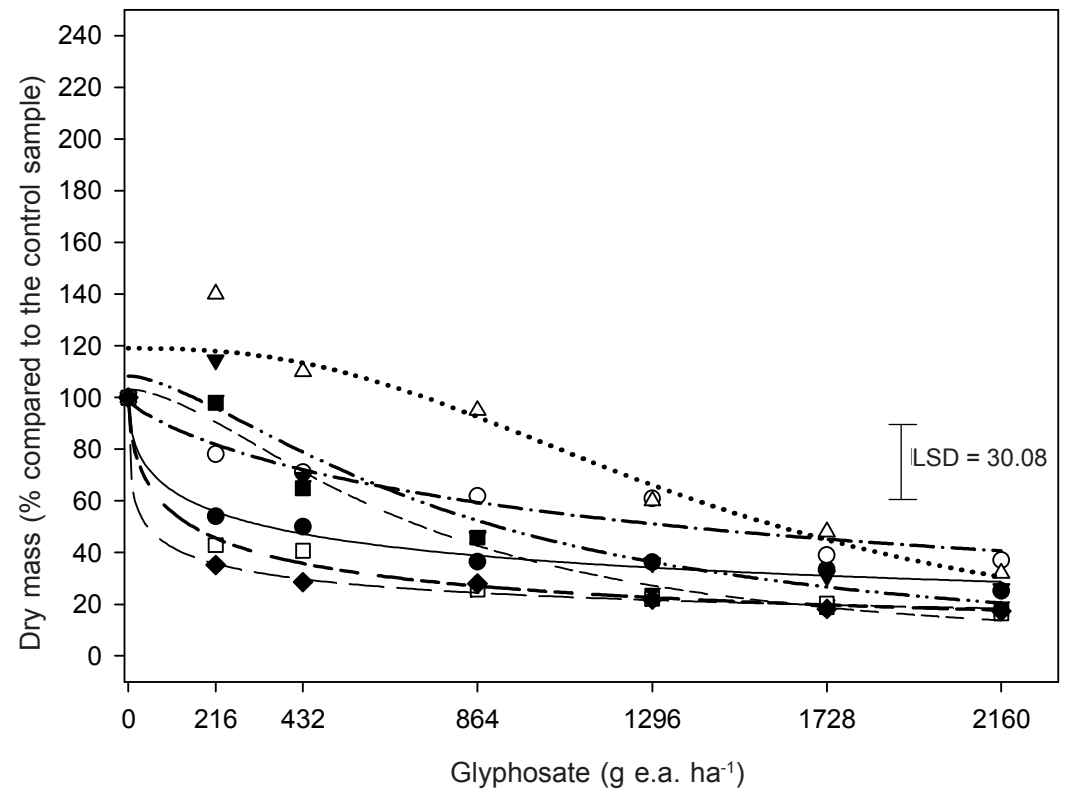

Figure 3 - Shoot dry mass in I. indivisa biotypes on day 28 after the application of glyphosate treatments. Averages compared by LSD test at $5 \%$ significance.

Table 3 - Parameters of the equations that were adjusted to shoot dry mass variable of I. indivisa biotypes after glyphosate application

\begin{tabular}{|c|c|c|c|c|c|c|}
\hline \multirow{2}{*}{ Biotype } & \multicolumn{4}{|c|}{ Parameter $^{(1)}$} & \multirow{2}{*}{$\mathrm{GR}_{80} * *$} & \multirow{2}{*}{ Tolerance factor } \\
\hline & A & $\mathrm{B}$ & $\mathrm{GR}_{50} *$ & $\mathrm{R}^{2}$ & & \\
\hline 1 & 99.93 & 0.49 & 346.10 & 0.98 & $>2,160$ & 7.32 \\
\hline 7 & 98.71 & 0.83 & 1407.60 & 0.91 & $>2,160$ & 28.96 \\
\hline 10 & 108.35 & 1.51 & 825.15 & 0.88 & 2,196 & 19.43 \\
\hline 20 & 118.94 & 2.52 & 1416.58 & 0.84 & 2,670 & 34.21 \\
\hline 23 & 103.08 & 1.66 & 700.74 & 0.97 & 1,644 & 15.45 \\
\hline 27 & 99.92 & 0.58 & 159.53 & 0.98 & 1,674 & 3.38 \\
\hline $30^{(1)}$ & 99.98 & 0.39 & 47.24 & 0.99 & 1,649 & 1.00 \\
\hline
\end{tabular}

(1) Three parameter logistic equation. $\mathrm{A}=$ maximum asymptote, $\mathrm{B}=$ curve gradient. $\mathrm{GR}_{50}=$ dose that provides a $50 \% \mathrm{SDM}_{\text {reduction. }} \mathrm{GR}_{80}=$ dose that provides a $80 \%$ SDM reduction. (2) Biotype collected in area with no glyphosate application. * Estimated through SigmaPlot program. ${ }^{* *}$ Estimated through Microsoft Excel program. 


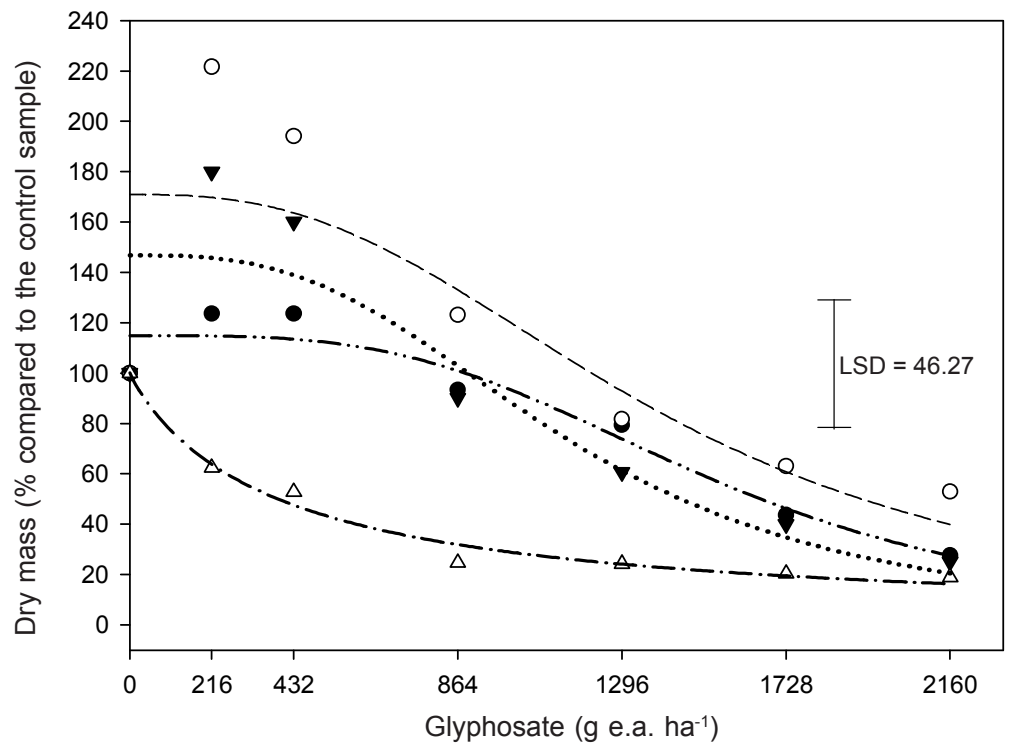

Averages compared by LSD test at $5 \%$ significance.

Figure 4 - Shoot dry mass in I. purpurea biotypes on day 28 after the application of glyphosate treatments.

Table 4 - Parameters of the equations that were adjusted to shoot dry mass variable of $I$. purpurea biotypes after glyphosate application

\begin{tabular}{|c|c|c|c|c|c|c|}
\hline \multirow{2}{*}{ Biotype } & \multicolumn{4}{|c|}{ Parameter $^{(1)}$} & \multirow{2}{*}{ GR $_{80}^{* *}$} & \multirow{2}{*}{ Tolerance factor } \\
\cline { 2 - 5 } & $\mathrm{A}$ & $\mathrm{B}$ & $\mathrm{GR}_{50}{ }^{*}$ & $\mathrm{R}^{2}$ & & 4.23 \\
\hline 9 & 114.88 & 3.41 & 1538.38 & 0.91 & 2,425 & 4.95 \\
\hline 17 & 170.91 & 2.66 & 1382.77 & 0.46 & 2,950 & 3.73 \\
\hline $25^{(2)}$ & 146.76 & 2.91 & 1155.56 & 0.71 & 2,178 & 1.00 \\
\hline 29 & 100.01 & 0.95 & 389.681 & 0.98 & 1,660 & \\
\hline
\end{tabular}

(1) Three parameter logistic equation. $\mathrm{A}=$ maximum asymptote, $\mathrm{B}=$ curve gradient. $\mathrm{GR}_{50}=$ dose that provides a $50 \% \mathrm{SDM}$ reduction. $\mathrm{GR}_{80}=$ dose that provides a $80 \%$ SDM reduction. ${ }^{(2)}$ Biotype collected in area with no glyphosate application. * Estimated through SigmaPlot program. ${ }^{* *}$ Estimated through Microsoft Excel program.

The response analysis of biotypes from Ipomoea spp. species to glyphosate is still a poorly explored topic in scientific literature. The comparative analysis of biotypes provides a broader vision on the response within the species, according to the existing genetic variability. The variability in glyphosate tolerance found in this study among biotypes and species disagrees with the one observed by Culpepper et al. (2001), who applied glyphosate doses on I. hederacea and I. purpurea biotypes; they detected an average control level of $92 \%$ for $I$. hederacea, whereas I. purpurea biotypes showed higher tolerance, with average control of $78 \%$ (Hookerton biotype) and $75 \%$ (Kinston biotype).

On day 14 DAA, the evaluation of 44 accesses of I. lacunosa, I. trichocarpa, I. quamoclit, I. hederacea and I. pupurea species which received $420 \mathrm{~g} \mathrm{ha}^{-1}$ glyphosate when the plants presented four to five leaves, detected wide response variability, in which $I$. hederacea, I. pupurea and I. quamoclit presented respective control levels of 9, 29 and 40\% (Burke et al., 2009). In the present work, a similar dose to the one used by Burke et al. (2009), of $420 \mathrm{~g} \mathrm{ha}^{-1}$, resulted in a $40 \%$ SDM reduction in the most sensitive $I$. purpurea biotype and in stimulatory effect for the other three tested biotypes (Figure 4).

The previous results indicate glyphosate response variability among biotypes from the three Ipomoea species. Response variability among biotypes from the same species may be due to the selection processes to which weed populations are submitted. Despite the fact that glyphosate is one of the main herbicides used in soybean cultures since the 1980's, it was with the introduction of genetically modified soybean cultivations that, from the year 2000, the use of this herbicide has been intensified, becoming the main selection agent of Ipomoea species. 
Repetitively using the same herbicide or herbicides with the same action mechanism and weed control spectrum for several years increases the risk of selecting resistant biotypes and species and biotypes with higher tolerance to the product (Monquero and Christoffoleti, 2005). Selection intensity and the evolution of glyphosate-tolerant species in cultivations vary according to cultivation and weed control systems adopted by farmers. In the work by Baucom and Mauricio (2004) with Ipomoea, they found strong evidences of positive directional selection in the presence of glyphosate and negative directional selection in the absence of this herbicide, which indicates that the way in which soil is used, determines the evolutionary direction of glyphosate tolerance.

Response variability in biotypes from the three Ipomoea species collected in this work is attributed to the evolutionary process, determined by various factors, among which there are initial frequency of the tolerance allele, dominance and pollination type of the species, size of the herbicide-treated area and infestation rate of the area and also herbicide action mechanism and its use frequency in the area.

The increase in herbicide doses to control tolerant populations that has been observed in cultures from different Brazilian regions probably reflects the accumulation of genes that give higher tolerance to biotypes. Thus, hypothetically, some gene may be responsible for a small reduction in herbicide absorption; another one for a small increase in herbicide metabolism; another one for a small increase in carriers action to the vacuole and, finally, another one for a small change in the herbicide action location, so that any combination may be responsible for tolerance increases compared to the isolated action of only one gene (De'Lye et al., 2013).

The increased tolerance levels in weed populations result in higher survival rates for the most tolerant individuals and mortality for the most sensitive ones, which increases the frequency of tolerance genes in the surviving population, leading to displacement or gradual increase in $\mathrm{C}_{50}$ values (Neve et al., 2009). Thus, it is believed that the populations with higher $\mathrm{C}_{50}$ values detected in this experiment are placed in a more advanced level in the process of selection by glyphosate.

Therefore, it is possible to state that there are no differences between the evolutionary process that determines increased tolerance, also referred as natural resistance by Duke (2011), and the evolutionary process that determines conventional resistance, characterized as the biotype ability to survive and reproduce after being exposed to an herbicide dose that would be lethal to a susceptible population of the same species (Christoffoleti, 2008).

It is possible to conclude that the biotypes from all tested Ipomoea species presented tolerance variability to the glyphosate herbicide. The highest variability occurred in I. grandifolia and I. indivisa species. Some biotypes need much higher doses than the one recommended to control field biotypes, indicating an evolution in the tolerance level to glyphosate herbicide. Thus, it is possible to validate the initial hypothesis of this work, that an intensive glyphosate use results in increased natural resistance levels to the herbicide and, consequently, in an accentuated response variability to the herbicide in populations from the same Ipomoea species.

\section{ACKNOWLEDGMENTS}

To the Coordenação de Aperfeiçoamento de Pessoal de Nivel Superior (CAPES) and the Conselho Nacional de Desenvolvimento Científico e Tecnológico (CNPq) for granting scholarships, and to the HRAC-BR, Universidade Tecnológica Federal do Paraná (UTFPR), for granting financial resources. And also to the agricultural cooperatives and private companies from the Southwestern region of Paraná state and the Western region of Santa Catarina state, which helped locating areas and collecting Ipomoea populations.

\section{REFERENCES}

Azania C.A.M. et al. Superação da dormência de sementes de corda-de-viola (Ipomoea quamoclit e I. hederifolia). Planta Daninha. 2009;27:23-7.

Baucom R.S., Mauricio R. The evolution of novel herbicide tolerance in a noxious weed: the geographic mosaic of selection. Evol Ecol. 2008;22:85-101. 
Burke I.C., Reddy K.N., Bryson, C.T. Pitted and hybrid morningglory accessions have variable tolerance to glyphosate. Weed Technol. 2009;23:592-8.

Cao S. et al. Ipomoeassins A-E, cytotoxic macrocyclic glicoresins from the leaves of Ipomoea squamosa from the Suriname rainforest. J Nat Produc. 2005;68:487-92.

Christoffoleti P.J. Aspectos da resistência de plantas daninhas a herbicidas. $3^{\mathrm{a}}$ ed. Piracicaba: HRAC-BR, 2008. 120p.

Culpepper A.S. et al. Morningglory (Ipomoea spp.) and large crabgrass (Digitaria sanguinalis) control with glyphosate and 2,4DB mixtures in glyphosate-resistant soybean (Glycine max). Weed Technol. 2001;15:56-61.

Degennaro F.P., Weller S.C. Differential susceptibility of field bindweed (Convolvulus arvensis) biotypes to glyphosate. Weed Sci. $1984 ; 32: 472-6$.

De'Lye C., Jasieniuk M., Le Corre V. Deciphering the evolution of herbicide resistance in weeds. Trends Genet. 2013;29:649-58.

Duke S. Glyphosate degradation in glyphosate-resistant and -susceptible crops and weeds. J Agric Food Chem. 2011;59:583541.

Duke S.O. et al. Hormesis: is it an important factor in herbicide use and allelopathy? Outlooks Pest Manage. 2006;17:29-33.

Galon L. et al. Tolerância de culturas e plantas daninhas a herbicidas. In: Agostinetto D., Vargas L. Resistência de plantas daninhas a herbicidas no Brasil. Passo Fundo: Berthier, 2009. p.37-74

Jordan, D.L. et al. Influence of application variables on efficacy of glyphosate. Weed Technol. 1997;11:354-62.

Kapusta G., Krausz R.E., Matthews J.L. Soybean tolerance and summer annual weed control with glufosinate and glyphosate in resistant soybeans. Proc North Cent Weed Sci Soc. 1994;49:120.

Kissmann K.G., Groth D. Plantas infestantes e nocivas. 2a . ed. São Paulo: BASF, 1999. Tomo II. 978p.

Lorenzi H., Souza V.C. Plantas ornamentais no Brasil: arbustivas, herbáceas e trepadeiras. $3^{\mathrm{a}}$. ed. Nova Odessa: Plantarum, 2001. 448p.

Monquero, P.A. et al. Absorção, translocação e metabolismo do glyphosate por plantas tolerantes e suscetíveis a este herbicida. Planta Daninha. 2004;22:445-51.

Monquero P.A., Christoffoleti P.J. Banco de sementes de plantas daninhas e herbicidas como fator de seleção. Bragantia. 2005;64:203-9.

Neve P., Vila-Aiub M., Roux F. Evolutionary-thinking in agricultural weed management. New Phytol. 2009;184:783-93.

Norsworthy J.K., Oliver L.R. Effect of irrigation, soybean (Glycine max) density, and glyphosate on hemp sesbania (Sesbania exaltata) and pitted morningglory (Ipomoea lacunosa) interference in soybean.Weed Technol. 2002;16:7-19.

Ogunwenmo K., Ugborogho R.E. Effects of chemical and mechanical scarification on seed germination of five species of Ipomoea (Convolvulaceae). Bull Soc Broter. 1999;69:147-62.

Pazuch D. et al. Superação de dormência em sementes de três espécies de Ipomoea. Ci Rural. 2015;45:192-9.

Powles S.B., Yu Q. Evolution in action: plants resistant to herbicides. Ann Rev Plant Biol. 2010;61:317-47.

Sigmaplot. Sigmaplot for windows, version 10.0. Systat Software, 2006. 